\title{
Pharmaconutrition in the Clinical Management of COVID-19: A Lack of Evidence-Based Research But Clues to Personalized Prescription
}

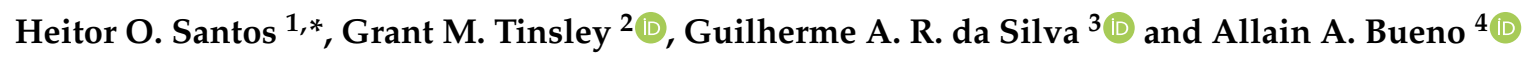 \\ 1 School of Medicine, Federal University of Uberlandia (UFU), Uberlandia 38408-100, Brazil \\ 2 Department of Kinesiology and Sport Management, Texas Tech University, Lubbock, TX 79409, USA; \\ grant.tinsley@ttu.edu \\ 3 Hospital Universitário Gaffrée e Guinle, Federal University of the State of Rio de Janeiro (UNIRIO), Rio de \\ Janeiro 21941-901, Brazil; drguialmeida@gmail.com \\ 4 College of Health, Life and Environmental Sciences, University of Worcester, Worcester WR2 6AJ, UK; \\ a.bueno@worc.ac.uk \\ * Correspondence: heitoroliveirasantos@gmail.com; Tel.: +55-34-992112948; Fax: +55-34-3225-8628
}

Received: 4 August 2020; Accepted: 27 August 2020; Published: 25 September 2020

\begin{abstract}
A scientific interest has emerged to identify pharmaceutical and nutritional strategies in the clinical management of coronavirus disease 2019 (COVID-19). The purpose of this narrative review is to critically assess and discuss pharmaconutrition strategies that, secondary to accepted treatment methods, could be candidates in the current context of COVID-19. Oral medicinal doses of vitamin C (1-3 g/d) and zinc ( $80 \mathrm{mg} / \mathrm{d}$ elemental zinc) could be promising at the first signs and symptoms of COVID-19 as well as for general colds. In critical care situations requiring parenteral nutrition, vitamin C (3-10 g/d) and glutamine (0.3-0.5 g/kg/d) administration could be considered, whereas vitamin D3 administration (100,000 IU administered intramuscularly as a one-time dose) could possess benefits for patients with severe deficiency. Considering the presence of n-3 polyunsaturated fatty acids and arginine in immune-enhancing diets, their co-administration may also occur in clinical conditions where these formulations are recommended. However, despite the use of the aforementioned strategies in prior contexts, there is currently no evidence of the utility of any nutritional strategies in the management of SARS-CoV-2 infection and COVID-19. Nevertheless, ongoing and future clinical research is imperative to determine if any pharmaconutrition strategies can halt the progression of COVID-19.
\end{abstract}

Keywords: severe acute respiratory syndrome coronavirus 2; SARS-CoV-2; coronavirus disease 2019; COVID-19; nutrition; supplementation

\section{Introduction}

With the emergence of severe acute respiratory syndrome coronavirus 2 (SARS-CoV-2)/coronavirus disease 2019 (COVID-19) worldwide, alongside substantial concern regarding the mortality rates in 2020 [1], extensive biomedical research has been devoted to mitigate this pandemic. In addition to the basic protective measures against the new coronavirus recommended by the World Health Organization (WHO) [2] (e.g., washing hands and social distancing), there is a fervent scientific interest in evaluating effective pharmacotherapy treatment of COVID-19 [3,4]. These endeavors are not limited to pharmaceutical agents, as several recent reports have considered the potential role of nutraceutical agents and proposed dosing regimens for vitamins, minerals, amino acids, and herbal medicines in this context [5-7]. However, the question remains: to what extent, if any, are nutraceutical agents and 
pharmaconutrition strategies useful against COVID-19 when applied in tandem with recommended clinical management?

While the term nutraceuticals is broadly defined and relatively vague [8,9], this category of substances can include dietary supplements, in general, herbal medicines and "functional foods". In contrast, pharmaconutrition is considered as a clinical nutrition therapy based on nutrients commonly provided in medical care via oral, enteral (i.e., administration into gastrointestinal tract), or parenteral (i.e., administration into the bloodstream) routes [10,11]. Given the more rigorous implementation of pharmaconutrition, and its importance for outpatient and inpatient treatments, we performed a literature review focusing on the use of well-known nutrients possessing pharmacological effects, particularly in critical care environments such as the intensive care unit (ICU), which could possibly be useful in the present COVID-19 pandemic due to their previously established clinical outcomes and safety record [12-14].

\section{Methods}

We employed a literature search using the Medline/PubMed database to identify preferentially meta-analyses of randomized clinical trials (RCTs) that investigated the administration of nutrients with pharmacological effects used in some clinical settings, particularly in critical care environments such as the intensive care unit (ICU). In addition, we considered original studies in order to complement meta-analyses. Evidence was reviewed regarding the administration of vitamin $C$ (ascorbic acid), vitamin D, zinc, omega-3 (n-3) polyunsaturated fatty acids (PUFA), glutamine, and arginine, as these are nutritional elements with physiological importance for the immune system and may be found within immune-enhancing diets (i.e., a formula containing arginine, n-3 PUFA, glutamine, nucleotides, and structured lipids); additionally, some of these nutraceutical components possess in vitro antiviral effects $[15,16]$. We primarily discuss recent meta-analyses to inform and encourage better clinical decision-making of practitioners and to provide insights for future COVID-19 RCTs.

\section{Vitamin C}

Apart from the pivotal role of endogenous antioxidants, antioxidant supplements have drawn attention against pathogens in the immune system [17-19]. Vitamin C is a potent antioxidant that scavenges oxygen free radicals and restores other cellular antioxidants; as such, this nutrient is suggested to improve viral-induced oxidative injury [20].

Indeed, there is a close link between vitamin $C$ and the immune system as this nutrient is considered an essential factor in the function of phagocytes, transformation of $\mathrm{T}$ lymphocytes, and production of interferon [21]. Accordingly, vitamin C is highly concentrated in white blood cells such as lymphocytes and macrophages [20]. Due to the increased inflammatory response and metabolic demand during infectious diseases as well as their associations with low circulating vitamin $C$ concentrations, vitamin $C$ administration may be beneficial in combatting a number of viral infections mainly by increasing the production of $\alpha / \beta$ interferons and downregulating the production of pro-inflammatory cytokines $[20,22]$.

Regarding clinical effects, in a meta-analysis of RCTs that examined $\geq 0.2 \mathrm{~g} / \mathrm{d}$ of oral vitamin C, there was no reduction in the incidence of colds, but in adults, the duration of colds was decreased by $8 \%$ (95\% confidence interval (CI): $3 \%$ to $12 \%$ ) [23]. Apart from this incipient outcome, the impact of administering vitamin $C$ under intensive care deserves attention in order to ascertain whether or not it meaningfully influences primary endpoints. In this regard, one meta-analysis demonstrated that vitamin C administration reduced general ICU length of stay (LOS) by $8 \%$ on average [24]. In trials employing oral vitamin $\mathrm{C}$ administration, a total of six reports using 1-3 g/d (weighted mean $2 \mathrm{~g} / \mathrm{d}$ ) decreased the general ICU LOS by $8.6 \%$ (95\% CI: 3.0\% to $14.0 \%$ ). In addition, three trials in which patients required mechanical ventilation for over $24 \mathrm{~h}$ indicated that vitamin $\mathrm{C}$ administration shortened the duration of mechanical ventilation by $18.2 \%$ (95\% CI: $7.7 \%$ to $27 \%$ ). However, it is worth 
mentioning that in this meta-analysis [24], 18 controlled trials were selected regardless of placebo treatment, and 13 of these studies were carried out on patients undergoing elective cardiac surgery.

Vitamin C therapy in ICU conditions generally consists of high doses administered for short periods (i.e., days or weeks), whereas a putative prophylaxis against viral infections may require extended periods (i.e., several months). Accordingly, high-dose vitamin C administration should only receive consideration as a potential complementary therapy in the context of critical care, while a nutritious diet including green vegetables, citrus fruits (e.g., oranges, lemons, grapefruit, Persian lime), and other foods containing this nutrient is sufficient to maintain adequate vitamin $C$ status in the general population. Importantly, it should be emphasized that the pharmacokinetic characteristics differ between oral and intravenous administration of vitamin C. Accordingly, intravenous administration can yield 30-to 70-fold higher blood concentrations of vitamin $C$ than the maximum tolerated oral dose [25]. Ultimately, clinical trials should determine whether hospitalized patients infected with SARS-CoV-2 show low plasma concentrations of vitamin C in order to inform the potential usefulness of administering this micronutrient.

\section{Zinc}

Zinc supplementation is recommended for the treatment of various ailments as a means of modulating anti-inflammatory and antioxidant pathways in several systems as well as regulating the immune system by T cell-mediated functions [26,27]. In general, a large body of evidence shows that up to one year of pharmacological zinc doses $(220 \mathrm{mg} / \mathrm{d}$ to $660 \mathrm{mg} / \mathrm{d}$ in chelated form, corresponding to approximately $50 \mathrm{mg}$ to $150 \mathrm{mg}$ of elemental zinc) seems to be a safe strategy in various clinical conditions, patient populations (i.e., from children to the elderly), and for patients with complicated diseases such as liver and kidney disease or diabetes mellitus [26,28-31]. The viability of supplementing zinc in elderly patients may be particularly salient due to the elevated mortality of aged patients with COVID-19 when compared with young and middle-aged subjects [32]. Moreover, preclinical data suggests that intracellular zinc inhibits the replication of SARS-CoV [33].

Zinc's best-documented effects against viral illness are likely those pertaining to the common cold. In a meta-analysis of placebo-controlled trials [34], acute medicinal provision of zinc reduced the duration of the common cold by approximately three days. In that analysis, trials that employed zinc acetate lozenges in an elemental dose $>75 \mathrm{mg} / \mathrm{d}$ were included; however, only three studies were eligible due to exclusion of studies employing low doses of zinc. Importantly, participants from these studies were instructed to administer one lozenge (9-13 mg of elemental zinc per lozenge) every 2-3 $\mathrm{h}$ while awake, thereby achieving a dose of $\sim 80 \mathrm{mg} / \mathrm{d}$ elemental zinc for one to two weeks. Lozenge use began immediately after the first common cold symptoms [35-37]. While zinc lozenges may be a viable option that could be offered to patients, the high frequency of daily administration necessary to achieve a medicinal dosage could be impractical; conversely, administration is recommended for only 1-2 weeks in an attempt to improve an acute clinical condition.

In another meta-analysis using medicinal doses of zinc, the mean common cold duration was $33 \%$ (95\% CI: $21 \%$ to $45 \%$ ) shorter for those receiving zinc supplementation [38]. Interestingly, Hemilä separately analyzed two zinc salts; three trials resulted in $40 \%$ shorter cold duration when using acetate zinc lozenges, and four trials resulted in $28 \%$ shorter cold duration when using zinc gluconate. However, the apparent $12 \%$ difference between the zinc forms was not definitive ( $95 \%$ CI: -12 to $+36 \%$ ). Regarding the elemental zinc doses, five trials [35-37,39,40] used 80-92 mg/d and two trials [41,42] used 192-207 mg/d, which reduced the common cold duration by 33\% and 35\%, (LOS respectively, without statistical difference between doses. Hence, the use of zinc doses over $100 \mathrm{mg} / \mathrm{d}$ are not necessary in this context.

\section{Vitamin D}

Vitamin D, a micronutrient possessing some known hormonal actions, has proposed anti-viral effects; however, the interplay between vitamin $\mathrm{D}$ and viral infections is yet to be fully elucidated $[43,44]$. 
Nonetheless, it appears that vitamin D promotes antiviral activity in airway epithelial cells during infection $[45,46]$. Additionally, low vitamin D status is associated with higher rates of upper and lower respiratory tract infections. From a broader perspective, severe 25-hydroxyvitamin D $(25(\mathrm{OH}) \mathrm{D})$ deficiency is associated with many chronic diseases $[47,48]$. While the challenge of defining whether low $25(\mathrm{OH}) \mathrm{D}$ status is the cause or consequence of specific chronic diseases remains, severe deficiency $(<10 \mathrm{ng} / \mathrm{mL})$, but not deficiency $(10 \sim 20 \mathrm{ng} / \mathrm{mL})$ or insufficiency $(20 \sim 30 \mathrm{ng} / \mathrm{mL})$, at point of admission is independently associated with increased risk of mortality in patients with sepsis [49]. At the same time, worsening severity of $25(\mathrm{OH}) \mathrm{D}$ deficiency is associated with increased LOS and mortality rate in general surgery patients admitted to the surgical ICU as well as higher ICU treatment cost [43].

Upon administration of vitamin D in the VITdAL-ICU trial [50], lower hospital mortality was noted in critically ill patients with severe $25(\mathrm{OH}) \mathrm{D}$ deficiency who received high-dose vitamin D3 when compared to placebo. Notwithstanding this result, it is critical to note that the study design involved a 540,000 IU vitamin D3 dose via oral or nasogastric tube followed by monthly maintenance doses of 90,000 IU for five months, producing a total follow-up time of six months, thus being potentially inapplicable to the acute care of patients infected with COVID-19. In one meta-analysis [51] encompassing six RCTs with 695 critically ill patients, no differences in infection rate, ventilation days, LOS in the ICU or hospital, or mortality were found with vitamin D administration. Even $>300,000$ IU of vitamin D3 daily, irrespectively of route (orally, via naso/oro-gastric tube, or intramuscularly) did not improve mortality. Overall, when viewed collectively, there is insufficient evidence to affirm that vitamin D administration improves clinical outcomes in critically ill patients.

Importantly, a recent study [52] examining 449 patients with COVID-19 from UK Biobank detected an initial association between low 25(OH)D levels and COVID-19 (OR $=0.99 ; 95 \%$ CI: $0.99-0.999)$, but not after adjustment for confounders (OR $=1.00 ; 95 \%$ CI: 0.998-1.01). This finding ultimately does not support a link between vitamin D concentrations and COVID-19. Additionally, while race/ethnicity was associated with COVID-19 univariably (Blacks vs. Whites OR $=5.32,95 \%$ CI: 3.68-7.70; South Asians vs. Whites OR $=2.65,95 \% \mathrm{CI}: 1.65-4.25)$, adjustment for 25(OH)D levels did not meaningfully alter the magnitude of the associations.

Given the paucity of scientific support for administration of vitamin D in the context of COVID-19, it is reasonable to screen $25(\mathrm{OH}) \mathrm{D}$ levels in patients with immune disturbances so that, in the case of deficiency, recommended practices can be followed. The Endocrine Society recommendations [44] state that the following doses should be employed in the event of deficiency: (1) 50,000 IU of vitamin D2 or D3 once a week for 8-wk program; (2) the equivalent of $6000 \mathrm{IU} / \mathrm{d}$ of vitamin D2 or D3, with maintenance therapy of 1500-2000 IU/d; or (3) 100,000 IU of vitamin D every four months.

\section{Omega-3 Polyunsaturated Fatty Acids}

Biochemically, PUFA appears to inactivate human-infecting enveloped viruses, and there is an association of higher intake of PUFA with reduced risk of pneumonia [53,54]. The n-3 PUFA are known to influence aspects of innate and adaptive immunity through a variety of mechanisms including beneficial effects on the cell membrane and roles in cell signaling [55]. As such, several investigations have sought to establish whether n-3 PUFA influences clinical outcomes in critical care settings.

Overall results from the meta-analysis of Koekkoek et al. [56] did not substantiate significant effects of enteral fish oil supplementation on 28-day ICU or hospital mortality in critically ill patients. However, ICU LOS and the ventilation duration were significantly reduced in patients who received fish oil supplementation, and there was a significant reduction in 28-day mortality in patients with acute respiratory distress syndrome (ARDS). Notwithstanding these benefits, the authors reported a low methodological quality of the studies performed on ARDS, which was seemingly caused by heterogeneity and some differences in the controlled diets such as the addition of other immunomodulatory substances (e.g., antioxidants, arginine, and glutamine).

Another meta-analysis examining critically ill patients with ARDS was also performed [57]. Compared to the placebo, n-3 PUFA added to enteral immunomodulatory diets improved early 
(3-4 d) and late (7-8 d) arterial partial pressure of oxygen $\left(\mathrm{PaO}_{2}\right) /$ fractional inspired oxygen $\left(\mathrm{FiO}_{2}\right)$ ratio, a marker used to quantify the severity of the ARDS, but mortality, hospital LOS, and infectious complications did not change. In addition, the authors reported trends for the beneficial effects in those who received n-3 PUFA with respect to reduced ICU LOS $(p=0.08)$ and length of mechanical ventilation $(p=0.06)$. Ultimately, the authors [57] concluded that administering $n-3$ PUFAs appears to be viable strategy in ARDS. In another meta-analysis of septic patients [58], n-3 PUFA administration failed to reduce mortality and the LOS of hospital and intensive care, but the duration of mechanical ventilation was shortened (weighted mean difference $=-3.82 ; 95 \%$ CI: -4.61 to -3.04 ).

At a minimum, n-3 PUFA administration could be considered in COVID-19 critical care situations based on its safety, common occurrence in immune-enhancing diets, and the ability to promote adequate n-3 PUFA status in the body. However, quantification of circulating levels of n-3 PUFA is a potential dilemma, as they are not usually measured in routine clinical practice. Correspondingly, only six of the 24 studies of the meta-analysis of Koekkoek et al. reported plasma levels of n-3 PUFA [56]. However, taking into account an insufficient intake of n-3 PUFA in many countries, particularly in those in which the general population habitually consumes fish at a low frequency, it may be admissible to employ n-3 PUFA as a complement to adequate nutrition of a critically ill patient regardless of blood levels. Overall, the n-3 PUFA dose for patients with ARDS in the meta-analysis of Koekkoek et al. was based on $5.3 \mathrm{~g} / \mathrm{L}$ eicosapentaenoic acid (EPA) via enteral nutrition, with only one study using n-3 PUFA soft gels $(720 \mathrm{mg})$ [56]. Therefore, the observed effects and proposed use are seemingly directed at EPA.

Unfortunately, the majority of clinical studies that have investigated the effects of $n-3$ PUFA administration did not test this nutrient alone, as n-3 PUFA was included within immune-enhancing diets or other nutritional strategies [56,57]. Importantly, Stapleton et al. examined the effect of n-3 PUFA administration, without other nutritional intervention, in patients with acute lung injury [59]. In a randomized placebo-controlled design, patients who received enteral fish oil administration ( $9.75 \mathrm{~g}$ EPA and $6.75 \mathrm{~g}$ docosahexanoic acid [DHA] daily) for up to 14 days did not present significant change in bronchoalveolar lavage fluid interleukin (IL)- 8 from baseline to day 4 or day 8 when compared to the placebo (saline infusion). Likewise, organ failure score, ventilator-free days, ICU-free days, and 60-day mortality did not differ between the groups.

\section{Arginine}

Arginine is a non-essential amino acid in the normal physiological state (i.e., it is sufficiently synthesized in the human body to meet the needs for growth and health [60]). However, arginine becomes conditionally essential during critical periods such as, for example, when burn patients are receiving total parenteral nutrition [61,62]. Mechanistically, arginine and its related pathways play a pivotal role in the pathophysiology of respiratory illnesses (e.g., asthma), mainly via the enzymatic inter-relationships between arginase and nitric oxide synthase (NOS) [63]. Within this biochemical reaction, there is competition between both enzymes for arginine as a substrate, from which nitric oxide (NO), a small gaseous signaling molecule, is produced by isoforms of NOS while arginase decreases NO biosynthesis [64]. Patients with pulmonary arterial hypertension show increased arginase level and decreased NO synthesis when compared to healthy controls [65]. In addition, patients with cystic fibrosis also present dysregulation in the arginine metabolic pathway, as demonstrated by a study [66] in which reduced systemic bioavailability of arginine was detected in this population compared to healthy non-smokers.

In the aforementioned clinical conditions, circulating arginine levels may be considered as a surrogate disease biomarker; however, this does not necessarily imply that administration of arginine is a viable treatment. For instance, in patients with cystic fibrosis, systemic arginine concentrations were normalized after two weeks of antibiotic treatment used for pulmonary disease exacerbation [66]. Concerning arginine supplementation in pulmonary disorders, some studies $[67,68]$ have demonstrated metabolic and clinical benefits in patients with asthma and pulmonary hypertension such as increases in plasma arginine levels and reduction of estimated pulmonary artery systolic pressure. Nevertheless, 
these are preliminary findings based on a limited number of individuals. Cumulatively, effects of arginine administration on lung function are potentially plausible and could be investigated in patients with SARS-CoV-2, as severe cases of this disease are associated with pneumonia and ARDS by virtue of worsening inflammatory-induced lung injury [69]. At a minimum, this amino acid is important for stimulating immune function via its impact on lymphocytes and macrophages, and its administration is proposed to attenuate clinical infections and shorten hospital LOS [61]. While many dietary sources of arginine are present in the food supply, higher doses of 15 to $30 \mathrm{~g} / \mathrm{d}$ of supplemental arginine are commonly used for critically ill patients [61]. Therefore, in a similar way to n-3 PUFA, arginine could be administered within immune-enhancing diets when deemed appropriate.

Despite indications that supplemental arginine administration is safe in the aforementioned dosages [70], caution should be exercised due to potential drug-supplement interactions. For example, risk of hypotension in the event of concurrent administration of arginine alongside blood pressure medication could result in cardiopulmonary instability in patients with concurrent cardiac dysfunction and/or pulmonary hypertension.

\section{Glutamine}

Glutamine is a conditionally essential amino acid that serves as a critical fuel source for cells of the immune system [71]. Additionally, the high demand for glutamine can cause a reduction in free glutamine concentrations during periods of pronounced physiological stress including major infection [72]. Glutamine supplementation is a strategy that may be useful in clinical settings due to its immunomodulatory effects [73]. The "cytokine storm" observed in patients with COVID-19 refers to an early response of pro-inflammatory cytokines, specifically tumor necrosis factor- $\alpha$ (TNF- $\alpha$ ), IL-6, and IL-1 $\beta$ [74]. Interestingly, glutamine administration could be a candidate for attenuating this cytokine storm as it may reduce the release of pro-inflammatory cytokines such as TNF- $\alpha$, IL-6, and IL-8, while increasing the concentrations of IL-10, an anti-inflammatory cytokine $[75,76]$.

In a meta-analysis of RCTs addressing critically ill adult patients (i.e., major surgery, trauma, infection, or organ failure), glutamine dipeptide administration via parenteral route $(0.3-0.5 \mathrm{~g} / \mathrm{kg} / \mathrm{d})$ significantly reduced infectious complications (relative risk $(R R)=0.70,95 \%$ CI: 0.60, 0.83), ICU LOS ( -1.61 days, 95\% CI: $-3.17,-0.05)$, hospital LOS $(-2.30$ days, 95\% CI: $-4.14,-0.45)$, mechanical ventilation duration $(-1.56$ days, $95 \% \mathrm{CI}:-2.88,-0.24)$, and mortality rate (RR $=0.55,95 \% \mathrm{CI}$ : $0.32,0.94)$, but had no effect on ICU mortality [77]. Importantly, this proposed glutamine regimen is in accordance with clinical guidelines $[78,79]$ and occurred as a complement to isoenergetic and isonitrogenous nutrition therapy. Alternatively, enteral glutamine supplementation does not generally confer significant clinical benefits in critically ill patients, as demonstrated in a meta-analysis that included only RCTs employing this route of administration [80]. Although there was a significant benefit in the subset of patients with burns, the pathophysiology of this condition is not comparable with the aggravated presentation observed in COVID-19.

It is not advisable to extrapolate glutamine supplementation as a means of improving immune function of the general population, since the primary indication for glutamine administration relates to critical medical conditions [81]. Correspondingly, a recent meta-analysis demonstrated that glutamine supplementation had no effect on athletes' immune systems [82]. Ultimately, a balanced diet is sufficient to maintain adequate glutamine status in healthy individuals, and supplementation should not be viewed as a beneficial preventative strategy. In critical COVID-19 cases, clinicians and researchers could consider examination of glutamine concentrations in order to further inform whether administration of this amino acid could hold a potential benefit for improving clinical outcomes.

\section{Pharmaconutrition in Patients with Diabetes}

Recently, in a cohort of 7337 COVID-19 patients, those diagnosed with diabetes demonstrated an increased need for medical interventions and higher mortality risk, with well-controlled blood glucose levels being correlated with better outcomes [83]. When considering the pharmaconutrition strategies 
discussed in this review, therapeutic doses of glutamine may reduce blood glucose concentrations of outpatients with diabetes and mitigate the hyperglycemia of critically ill diabetic patients under total parenteral nutrition [84]. Moreover, medicinal dosages of zinc and vitamin $C$ appear to reduce blood glucose levels in patients with diabetes, as supported by the results of recent meta-analyses $[29,85,86]$. However, these effects have been observed in non-COVID-19 situations.

Regarding mechanisms of action, glutamine is an efficacious glucagon-like peptide (GLP)-1 secretagogue, and when administered with a meal, increases both GLP-1 and insulin secretion, resulting in reduced postprandial blood glucose in subjects with type 2 diabetes [84]. As such, it was demonstrated that glutamine administration mitigated the hyperglycemia of critically ill diabetic patients on total parenteral nutrition [84], a route of administration frequently associated with high levels of blood glucose [87]. The effects, if any, of vitamin C and zinc on blood glucose have not been clearly elucidated; however, their antioxidant potential could potentially be beneficial as a means of decreasing reactive oxygen species, which are produced intensely in patients with diabetes $[88,89]$.

\section{Strengths and Limitations}

In contrast with other recent reviews [5-7], we intentionally did not focus on herbal medicines since their use is uncommon in intensive care. Conversely, vitamins, minerals, and amino acids are essential for the body, are utilized in medical care settings, and may be administrated beyond the oral route. Most importantly, the ongoing pharmaconutrition trials for the treatment of COVID-19 are focusing on vitamins and minerals (Table 1). The focus on nutrients with established utility in clinical nutrition as well as those currently being examined in preliminary COVID-19 trials is a strength of the present review as we attempted to avoid misconceptions and unsubstantiated recommendation of substances without applicability in critical situations. However, it is also recognized that herbal medicines are a pertinent tool as an adjuvant to medical therapies in specific outpatient scenarios (e.g., type 2 diabetes mellitus [90], dyslipidemia [91,92] etc.)

Despite a number of meta-analyses [24,34,38,51,56-58,77,80] addressing the use of pharmaconutrition to combat illness, most are limited due to the studies' heterogeneity (Table 2). Unfortunately, heterogeneity is a common concern in meta-analyses [93]. Thus, while awareness of this and other limitations is essential, meta-analytical techniques are still a fundamental component for critically appraising the existing evidence and informing decision-making that, in turn, covers the wide diversity observed in clinical practice. 
Table 1. Ongoing pharmaconutrition-related trials, as registered on https://clinicaltrials.gov/. Search carried out on 4 August 2020.

\begin{tabular}{|c|c|c|c|c|c|}
\hline Interventions & Conditions & Estimated Enrollment $(n)$ & Phase & Country & Clinical Trial ID \\
\hline $\begin{array}{l}\text { Vitamin C 2-h infusion daily (for } 6 \mathrm{~d} \text { ), escalating dose }(0.3 \mathrm{~g} / \mathrm{kg} \text {, } \\
0.6 \mathrm{~g} / \mathrm{kg}, 0.9 \mathrm{~g} / \mathrm{kg} \text { ). }\end{array}$ & $\begin{array}{l}\text { Hospitalized patients } \\
\text { with COVID-19 }\end{array}$ & 66 & Recruiting & USA & NCT04363216 \\
\hline $\begin{array}{l}50 \mathrm{mg} / \mathrm{kg} \text { vitamin } \mathrm{C} \text { infusion given every } 6 \mathrm{~h} \text { for } 4 \mathrm{~d} \text { (16 total } \\
\text { doses) }\end{array}$ & COVID-19 and hypoxia & 20 & Recruiting & USA & NCT04357782 \\
\hline $10 \mathrm{~g}$ of IV vitamin $\mathrm{C}$ in addition to conventional therapy & $\begin{array}{l}\text { Hospitalized patients with } \\
\text { COVID-19 pneumonia }\end{array}$ & 500 & Recruiting & Italy & NCT0432351 \\
\hline $\begin{array}{l}\text { Inpatients: IV vitamin C (Sodium Ascorbate) } 50 \mathrm{mg} / \mathrm{kg} \text { every } 6 \mathrm{~h} \\
\text { on d } 1 \text { followed by } 100 \mathrm{mg} / \mathrm{kg} \text { every } 6 \mathrm{~h}(4 \times / \mathrm{d} ; 400 \mathrm{mg} / \mathrm{kg} / \mathrm{d} \text { ) for } 7 \\
\mathrm{d} \text { (average } 28 \mathrm{~g} / \mathrm{d} \text { ). Outpatients: } 200 \mathrm{mg} / \mathrm{kg} \times 1 \mathrm{IV} \text { vitamin C, then } \\
1 \mathrm{~g} \text { PO } 3 \times / \mathrm{d} \text { for } 7 \mathrm{~d} \text {. Plus active comparator: } 400 \mathrm{mg} \text { PO } 2 \times / \mathrm{d} \\
\mathrm{Hydroxychloroquine,} \mathrm{followed} \mathrm{by} 200 \mathrm{mg} \text { PO } 2 \times / \mathrm{d} \text { for } 6 \mathrm{~d} .500 \\
\mathrm{mg} / \mathrm{d} \text { PO azithromycin followed by } 250 \mathrm{mg} / \mathrm{d} \text { PO for } 4 \mathrm{~d} .30 \mathrm{mg} / \mathrm{d} \\
\mathrm{PO} \text { (elemental dose) zinc citrate. } 5000 \mathrm{IU} / \mathrm{d} \text { PO vitamin } \mathrm{D} 3 \text { for } 14 \\
\mathrm{~d} .500 \mathrm{mcg} / \mathrm{d} \text { PO } \\
\text { vitamin B12 for } 14 \mathrm{~d} \text {. }\end{array}$ & COVID-19 & 200 & $\begin{array}{l}\text { Not yet } \\
\text { recruiting }\end{array}$ & Australia & NCT04395768 \\
\hline IV vitamin C: $50 \mathrm{mg} / \mathrm{kg}$ every $6 \mathrm{~h}$ for $96 \mathrm{~h}$ (16 doses). & $\begin{array}{l}\text { Hospitalized patients } \\
\text { with COVID-19 }\end{array}$ & 800 & $\begin{array}{l}\text { Not yet } \\
\text { recruiting }\end{array}$ & Canada & NCT04401150 \\
\hline Methylene blue, vitamin $\mathrm{C}$, N-acetyl cysteine & COVID-19 & 20 & Recruiting & Iran & NCT04370288 \\
\hline $\begin{array}{l}\text { Drug: hydroxychloroquine } \\
\text { Dietary supplements: vitamin C, vitamin D and zinc. Use as a } \\
\text { prophylaxis treatment for COVID-19 }\end{array}$ & COVID-19 & 600 & $\begin{array}{l}\text { Not yet } \\
\text { recruiting }\end{array}$ & USA & NCT04335084 \\
\hline $100 \mathrm{mg} / \mathrm{kg}$ intravenous vitamin $\mathrm{C}$ infusion every $8 \mathrm{~h}$ for up to $72 \mathrm{~h}$ & $\begin{array}{l}\text { COVID-19 Lung Injury, } \\
\text { Acute }\end{array}$ & 200 & $\begin{array}{l}\text { Not yet } \\
\text { recruiting }\end{array}$ & USA & NCT04344184 \\
\hline $\begin{array}{l}\text { Experimental: oral loading dose of } 800 \mathrm{mg} \text { followed by once } \\
\text { weekly oral hydroxychloroquine } 400 \mathrm{mg} \text { for } 3 \mathrm{mo} \text {. Active } \\
\text { comparator: oral vitamin C } 1 \mathrm{~g} / \mathrm{d} \text { for } 3 \mathrm{mo} \text {. }\end{array}$ & COVID-19 & 1212 & $\begin{array}{l}\text { Not yet } \\
\text { recruiting }\end{array}$ & USA & NCT04347889 \\
\hline $12 \mathrm{~g}$ vitamin C $2 \times / \mathrm{d}$ for $7 \mathrm{~d}$ with infused pump speed of $12 \mathrm{~mL} / \mathrm{h}$. & $\begin{array}{l}\text { COVID-19 pneumonia, } \\
\text { ventilator-associated }\end{array}$ & 140 & Recruiting & China & NCT04264533 \\
\hline
\end{tabular}


Table 1. Cont.

\begin{tabular}{|c|c|c|c|c|c|}
\hline Interventions & Conditions & Estimated Enrollment $(n)$ & Phase & Country & Clinical Trial ID \\
\hline $\begin{array}{l}\text { Comparator: ascorbic acid } 500 \mathrm{mg} \text { orally daily for } 3 \text {, then } 250 \mathrm{mg} \\
\text { orally daily for } 11 \text { d Experimental: hydrochloroquine } 400 \mathrm{mg} \\
\text { orally daily for } 3 \text { days, then } 200 \mathrm{mg} \text { orally daily for an additional } \\
11 \text { days }\end{array}$ & COVID-19 & 2000 & $\begin{array}{l}\text { Not yet } \\
\text { recruiting }\end{array}$ & USA & NCT04328961 \\
\hline $\begin{array}{l}\text { Quintuple therapy for } 24 \text { weeks Drugs: hydroxychloroquine and } \\
\text { azithromycin Dietary supplements: vitamin C, vitamin D, zinc }\end{array}$ & COVID-19 & 600 & $\begin{array}{l}\text { Not yet } \\
\text { recruiting }\end{array}$ & USA & NCT04334512 \\
\hline $\begin{array}{l}\text { Plaquenil } 200 \mathrm{mg} \text { tablet. } \\
\text { Proflaxis using hydroxychloroquine + Vitamin C, D and zinc } \\
\text { (Not specified dosage) }\end{array}$ & COVID-19 & 80 & Recruiting & Turkey & NCT04326725 \\
\hline $\begin{array}{l}\text { Daily oral nutrition supplement with: } 1.1 \mathrm{~g} \text { EPA, } 450 \mathrm{mg} \text { DHA, } \\
950 \mathrm{mg} \text { GLA, } 2840 \mathrm{IU} \text { vitamin A as } 1.2 \mathrm{mg} \beta \text {-carotene, } 205 \mathrm{mg} \\
\text { vitamin C, } 75 \mathrm{IU} \text { vitamin E, } 18 \mu \mathrm{g} \text { selenium, and } 5.7 \mathrm{mg} \text { zinc. } \\
\text { Taken } 3 \mathrm{~h} \text { after breakfast. }\end{array}$ & COVID-19 & 30 & $\begin{array}{l}\text { Not yet } \\
\text { recruiting }\end{array}$ & Saudi Arabia & NCT04323228 \\
\hline Vitamin C: $50 \mathrm{mg} / \mathrm{kg}$ every $6 \mathrm{~h}$ for $96 \mathrm{~h}$. & COVID-19, Sepsis, ICU & 800 & Recruiting & Canada & NCT03680274 \\
\hline $\begin{array}{l}8000 \mathrm{mg} \text { of ascorbic acid divided into } 2-3 \text { doses/d with food. } 50 \\
\mathrm{mg} \text { of zinc gluconate to be taken daily at bedtime. } \\
\text { Combined and single treatment. }\end{array}$ & COVID-19 & 520 & $\begin{array}{l}\text { Enrolling by } \\
\text { invitation }\end{array}$ & USA & NCT04342728 \\
\hline $\begin{array}{l}\text { Vitamin C } 3 \mathrm{~g} / \mathrm{d}, 400 \mathrm{mg} \text { tiamine, selenium, omega- } 3500 \mathrm{mg} / \mathrm{d} \text {, Vit } \\
\text { A, Vit D, Azithromycine, Ceftriaxone, Kaletra } 2 \times / \mathrm{d} \text { for } 10 \mathrm{~d} \text {. }\end{array}$ & COVID-19 & 80 & Recruiting & Iran & NCT04360980 \\
\hline $\begin{array}{l}\text { Single dose of } 25,000 \mathrm{UI} \text { of vitamin D supplement in addition to } \\
\text { prescription of NSAIDs, ACE2 inhibitor, ARB or } \\
\text { thiazolidinediones, according to clinician criteria. Vitamin D } \\
\text { supplementation will be taken in the morning together with a } \\
\text { toast with olive oil. }\end{array}$ & COVID-19 & 200 & $\begin{array}{l}\text { Not yet } \\
\text { recruiting }\end{array}$ & Spain & NCT04334005 \\
\hline $\begin{array}{l}\text { Experimental: } 400,000 \mathrm{IU} \text { vitamin D3 in a single oral dose. Active } \\
\text { Comparator: 50,000 IU in vitamin D supplementation a single } \\
\text { oral dose }\end{array}$ & COVID-19 & 260 & $\begin{array}{l}\text { Not yet } \\
\text { recruiting }\end{array}$ & France & NCT04344041 \\
\hline
\end{tabular}

ACE2 inhibitor: angiotensin-converting enzyme 2 inhibitor; ARB: angiotensin II receptor blocker; DHA: docosahexaenoic acid; EPA: eicosapentaenoic acid; ICU: intensive care unit; IV: intravenous therapy; GLA: gamma-linolenic acid; NSAIDs: nonsteroidal anti-inflammatory drugs. 
Table 2. Summary of main findings of the meta-analyses appraised in the current review. Collectively, those studies addressed pharmaconutrition strategies through randomized clinical trials with medical outcomes that show potential in the management of COVID-19.

\begin{tabular}{|c|c|c|c|c|c|c|c|c|}
\hline $\begin{array}{l}\text { Author, Year } \\
\text { (Reference) }\end{array}$ & $\begin{array}{l}\text { Supplement, } \\
\text { Route }\end{array}$ & Dose & Duration & Condition & Trials $(n)$ & Patients (n) & $\mathrm{I}^{2}$ & Main Results \\
\hline $\begin{array}{c}\text { Hemilä and } \\
\text { Chalker, 2013 } \\
{[18]}\end{array}$ & Vitamin C, oral & $\geq 0.2 \mathrm{~g} / \mathrm{d}$ & $\begin{array}{l}\text { According to } \\
\text { mean of cold } \\
\text { episodes }\end{array}$ & $\begin{array}{l}\text { General } \\
\text { community }\end{array}$ & 29 & 11,306 & $38 \%$ & $\begin{array}{l}\text { In adults, the duration of } \\
\text { colds was reduced by } 8 \% \text { and } \\
\text { in children by } 14 \%\end{array}$ \\
\hline $\begin{array}{l}\text { Wang et al., } \\
2019 \text { [19] }\end{array}$ & $\begin{array}{l}\text { Vitamin C, } \\
\text { intravenous }\end{array}$ & $450 \mathrm{mg} / \mathrm{d}$ to $66 \mathrm{mg} / \mathrm{kg} / \mathrm{h}$ & $12 \mathrm{~h}$ to 28 days & Critically ill & 12 & 1210 & $0 \%$ & $\begin{array}{l}\text { Reduced the duration of } \\
\text { vasopressor support and } \\
\text { mechanical ventilation. 3-10 } \\
\text { g vitamin C resulted in lower } \\
\text { overall mortality rates }\end{array}$ \\
\hline $\begin{array}{l}\text { Hemilä et al., } \\
2016 \text { [28] }\end{array}$ & Zinc, oral & $\begin{array}{l}\text { 80-92 mg/d elemental zinc } \\
\text { dose, acetate lozenges }\end{array}$ & $\begin{array}{l}\text { According to } \\
\text { cold episodes }\end{array}$ & Common cold & 3 & 199 & $61 \%$ & $\begin{array}{l}36 \% \text { ( } 3 \text { days) estimates for the } \\
\text { reduction of common cold } \\
\text { duration }\end{array}$ \\
\hline $\begin{array}{l}\text { Hemilä, } 2017 \\
{[32]}\end{array}$ & Zinc, oral & $\begin{array}{l}\text { 80-207 mg/d zinc acetate or } \\
\text { gluconate }\end{array}$ & $\begin{array}{l}\text { According to } \\
\text { cold episodes }\end{array}$ & Common cold & 7 & 575 & $77 \%$ & $\begin{array}{l}\text { Common cold duration was } \\
33 \% \text { shorter for the zinc } \\
\text { groups }\end{array}$ \\
\hline $\begin{array}{l}\text { Langlois et al., } \\
\quad 2018 \text { [45] }\end{array}$ & $\begin{array}{l}\text { Vitamin } \mathrm{D}, \\
\text { oro-enteral or } \\
\text { parenteral }\end{array}$ & $50,000-540,000 \mathrm{IU}$ & $\begin{array}{l}\text { Single dose to } 5 \\
\text { days }\end{array}$ & Critically ill & 6 & 695 & $0 \%$ & $\begin{array}{l}\text { No differences in ICU and } \\
\text { hospital LOS, infection rate } \\
\text { and ventilation day }\end{array}$ \\
\hline $\begin{array}{c}\text { Tao et al., } 2016 \\
{[52]}\end{array}$ & $\begin{array}{l}\text { Omega-3, } \\
\text { parenteral or } \\
\text { enteral }\end{array}$ & $\begin{array}{c}\text { According to commercially } \\
\text { available omega-3 fatty acids } \\
\text { enriched nutrition } \\
(\text { Omegaven } \\
\text { Lipolus }^{\circledR} \text { Oxepa }{ }^{\circledR} \text {, }\end{array}$ & $\begin{array}{l}\text { Varied across } \\
\text { different trials }\end{array}$ & Sepsis & 11 & 11,808 & $\begin{array}{c}40 \% \text { for } \\
\text { mechanical } \\
\text { ventilation and } \\
0 \% \text { for mortality }\end{array}$ & $\begin{array}{l}\text { Reduced mechanical } \\
\text { ventilation duration but not } \\
\text { mortality }\end{array}$ \\
\hline $\begin{array}{l}\text { Koekkoek et al., } \\
2019 \text { [50] }\end{array}$ & $\begin{array}{l}\text { Omega-3, } \\
\text { enteral }\end{array}$ & $0.68-16.5 \mathrm{~g} / \mathrm{L}$ & $\begin{array}{l}\text { Varied across } \\
\text { different trials }\end{array}$ & Critically ill & 24 & 3574 & $\begin{array}{l}2 \% \text { for overall } \\
\text { mortality and } \\
0 \% \text { for mortality } \\
\text { in patients with } \\
\text { ARDS }\end{array}$ & $\begin{array}{c}\text { Enteral fish oil } \\
\text { supplementation did not } \\
\text { change } 28-\mathrm{d} \text { mortality in } \\
\text { general, but reduced } \\
\text { mortality in patients with } \\
\text { ARDS }\end{array}$ \\
\hline
\end{tabular}


Table 2. Cont.

\begin{tabular}{|c|c|c|c|c|c|c|c|c|}
\hline $\begin{array}{l}\text { Author, Year } \\
\text { (Reference) }\end{array}$ & $\begin{array}{c}\text { Supplement, } \\
\text { Route }\end{array}$ & Dose & Duration & Condition & Trials $(n)$ & Patients $(n)$ & $\mathrm{I}^{2}$ & Main Results \\
\hline $\begin{array}{l}\text { Langlois et al., } \\
2019 \text { [51] }\end{array}$ & $\begin{array}{l}\text { Omega-3, } \\
\text { enteral or } \\
\text { parenteral }\end{array}$ & $\begin{array}{l}\text { According to commercially } \\
\text { available omega-3 fatty acids } \\
\text { enriched nutrition } \\
\left(\text { Omegaven }{ }^{\circledR}, \text { Oxepa }{ }^{\circledR},\right. \\
\text { Ultimate Omega }{ }^{\circledR} \text { ). Overall, } \\
1.3 \mathrm{~g} / \mathrm{d} \text { to } 10.2 \mathrm{~g} / \text { formula }\end{array}$ & $\begin{array}{l}\text { Varied across } \\
\text { different trials }\end{array}$ & $\begin{array}{l}\text { Critically ill } \\
\text { patients with } \\
\text { ARDS }\end{array}$ & 20 & 1280 & $\begin{array}{l}69 \% \text { for } \\
\mathrm{PaO}_{2} \text {-to-FiO } \\
\quad \text { ratio }\end{array}$ & $\begin{array}{l}\text { Improved early and late } \\
\mathrm{PaO}_{2} \text {-to--FiO }\end{array}$ \\
\hline $\begin{array}{l}\text { van Zanten et } \\
\text { al., } 2015 \text { [74] }\end{array}$ & $\begin{array}{l}\text { Glutamine, } \\
\text { enteral }\end{array}$ & 0.27 to $0.5 \mathrm{~g} / \mathrm{kg} / \mathrm{d}$ & $\begin{array}{l}\text { Varied across } \\
\text { different trials }\end{array}$ & Critically ill & 11 & 1079 & $52 \%$ for $\operatorname{LOS}$ & $\begin{array}{l}\text { There was no reduction of } \\
\text { hospital mortality, infectious } \\
\text { complications, or stay in the } \\
\text { ICU, but there was a } \\
\text { significant reduction in LOS } \\
\text { ( } \sim 5 \text { days) }\end{array}$ \\
\hline $\begin{array}{l}\text { Stehle et al. } \\
\text { 2017, [71] }\end{array}$ & $\begin{array}{l}\text { Glutamine } \\
\text { dipeptide, } \\
\text { parenteral }\end{array}$ & $\begin{array}{c}0.4-0.5 \mathrm{~g} / \mathrm{kg} / \mathrm{d} \\
\text { alanylglutamine } \\
\text { (alanine-glutamine) }\end{array}$ & 3-21 days & Critically ill & 16 & 842 & $\begin{array}{c}0 \% \text { for hospital } \\
\text { mortality, } 31 \% \\
\text { for infectious } \\
\text { complication, } \\
0 \% \text { for LOS }\end{array}$ & $\begin{array}{l}\text { Reduced hospital mortality, } \\
\text { infectious complication rates, } \\
\text { and hospital LOS }\end{array}$ \\
\hline
\end{tabular}

Overall, when the value of the $\mathrm{I}^{2}$ statistic is greater than $50 \%$, it can be regarded as heterogeneity [93]. Legend: ARDS, acute respiratory distress syndrome; ICU, intensive care unit; LOS, length of stay; $\mathrm{PaO}_{2}$-to- $-\mathrm{FiO}_{2}$ ratio, arterial partial pressure of oxygen/fractional inspired oxygen ratio. 


\section{Summary and Recommendations}

In light of the lack of scientific basis underpinning new nutrition strategies for the management of COVID-19 and its related consequences, the focus of the present work was to examine nutrients with immunological properties commonly used in the treatment of hospitalized patients, as summarized in Figure 1 through a diagram of tentative proposals. Prior to widespread implementation of pharmaconutrition strategies, it is crucial to verify the effects of the tentatively proposed therapies on recognized outcomes such as ICU and hospital mortality and inherited outcomes (e.g., ICU and hospital LOS, ventilation duration and infectious complications).

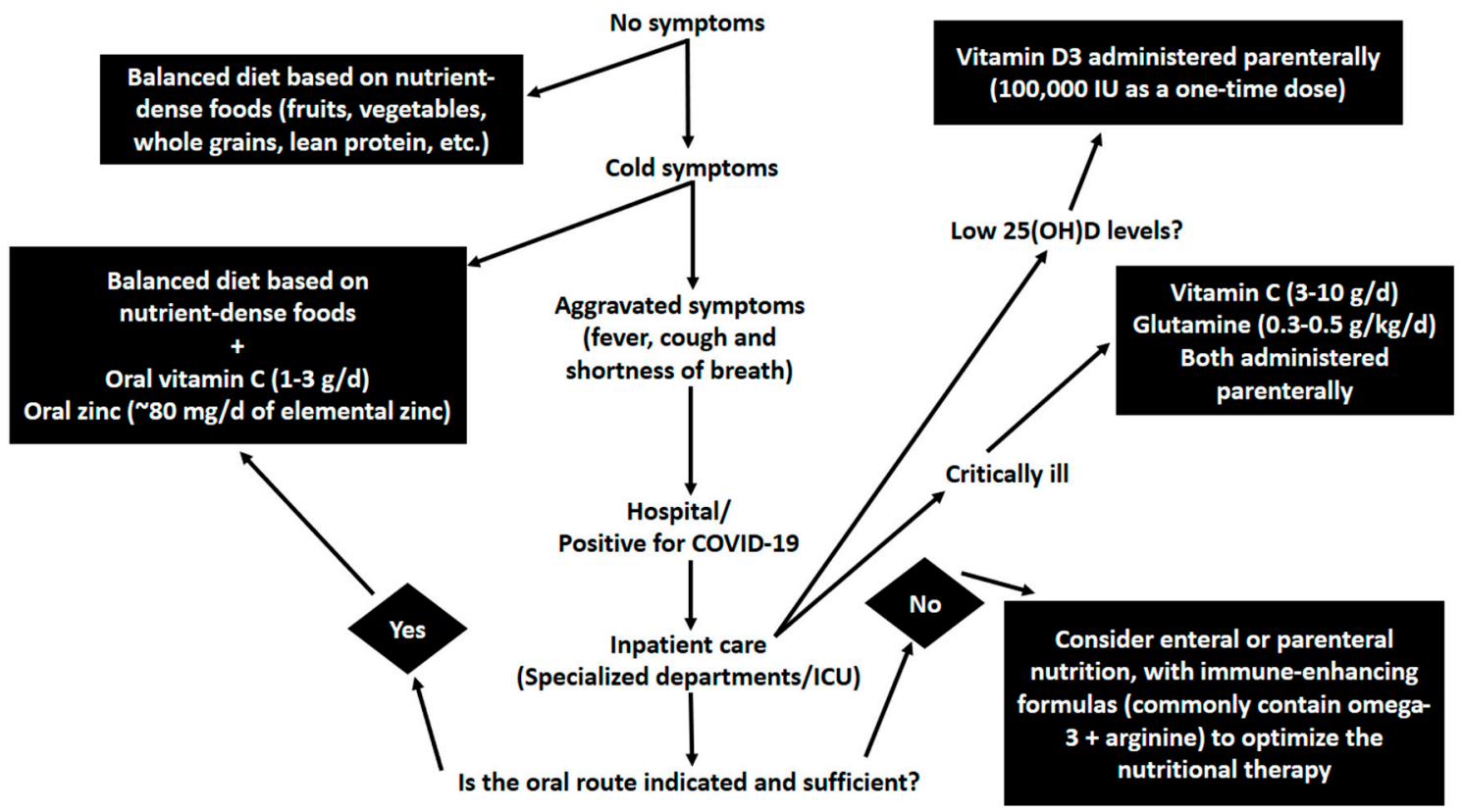

Figure 1. Possible adjunct pharmaconutrition in the management of COVID-19. All pharmaconutrition strategies displayed in this diagram should be considered in conjunction with established medical care guidelines. Additionally, such proposed roles are based on non-COVID-19 research and reflect the authors' interpretation of potentially relevant literature. Interventions should ideally be further assessed in clinical trial and cautiously administered under close medical care.

To the best of our knowledge and considering the current scenario, oral vitamin C (1-3 g/d) and zinc (80 mg/d elemental zinc) could be considered at the first signs and symptoms of COVID-19; parenteral vitamin C (3-10 g/d) and glutamine $(0.3-0.5 \mathrm{~g} / \mathrm{kg} / \mathrm{d})$ could be considered in critical care situations; vitamin D3 administration (100,000 IU as a one-time dose) could be appropriate for patients with severe deficiency, and co-administration of n-3 PUFA and arginine could be appropriately recommended in clinical conditions where immune-enhancing diets are recommended. Although blood levels of zinc do not necessarily indicate the intracellular zinc status [25], evaluating its concentrations as well as vitamin $\mathrm{C}$ and $25(\mathrm{OH}) \mathrm{D}$ may be important before administration, as these biomarkers are used in medical care settings by way of comparison with other nutrients and could influence subsequent clinical decision-making.

Overall, the appraised meta-analyses considered all pharmaconutrition strategies discussed in this review to be generally safe for administration to ill patients $[23,33,37,51,56-58,77,80]$. However, pharmaconutrition strategies should be employed under the guidance or supervision of qualified medical personnel, particularly given that the doses of minerals and vitamins considered may exceed the Tolerable Upper Intake Level (e.g., >40 mg/d zinc, $>2$ g/d vitamin C, > 2000 IU/d vitamin D) [94], while the parenteral route may be required for critical care settings. Prudence must be exercised so as 
not to culminate in unnecessary polypharmacy, which may affect the quality of life of patients and cause undesired reactions due to drug-nutrient interactions $[95,96]$.

Certainly, the administration of these nutrients should not be viewed as a sole strategy for the treatment of COVID-19 as it is critical to follow expert recommendations, ranging from basic protective measures endorsed by the $\mathrm{WHO}$, to established medical guidelines in intensive care settings. The identification and treatment of COVID-19 patients therefore involve a comprehensive team of health professionals (physician, nurse, dietitian, pharmacist, physical therapist, etc.). Finally, pharmaconutrition treatment is suggested as a possible acute support strategy, but not for prophylactic or long-term use.

\section{Conclusions}

To date, there is no direct evidence regarding the efficacy of particular nutraceutical strategies in the management of SARS-CoV-2 infection and COVID-19. However, given the relevance of the current global crisis and the knowledge that adequate nutrition is required for all members of society, decision-making should be based on the best existing scientific knowledge in this scenario. As discussed herein, oral medicinal doses of vitamin $C$ and zinc may potentially hold promise at the first signs and symptoms of COVID-19 as well as for general colds. Concerning critical care situations linked to COVID-19, not only is vitamin C administration plausible, but also glutamine when parenteral nutrition is recommended, while vitamin D3 administration could be useful for patients with severe deficiency. As n-3 PUFA and arginine are commonly present in immune-enhancing diets, their co-administration may occur in clinical conditions when these formulations are recommended. Collectively, while the clinical approaches are relatively well documented in prior contexts, these nutritional candidates only afford possible adjuvant effects to complement the recommended medical treatment of COVID-19. Further clinical research including the ongoing trials highlighted in the present review, should explore these nutritional strategies in the context of COVID-19 to establish new options for combating the devastating effects of this pandemic.

Author Contributions: Conceptualization, H.O.S.; Methodology, H.O.S.; Writing—original draft preparation, H.O.S.; Funding acquisition, A.A.B.; Supervision, G.A.R.d.S., G.M.T., and A.A.B. All authors have read and agreed to the published version of the manuscript.

Funding: This research was partially funded by the University of Worcester.

Conflicts of Interest: The authors declare no conflict of interest.

\section{References}

1. Onder, G.; Rezza, G.; Brusaferro, S. Case-fatality rate and characteristics of patients dying in relation to COVID-19 in Italy. JAMA 2020, 323, 1775-1776. [CrossRef] [PubMed]

2. WHO. Coronavirus Disease (COVID-19) Advice for the Public; WHO: Geneva, Switzerland, 2020.

3. Gautret, P.; Lagier, J.C.; Parola, P.; Hoang, V.T.; Meddeb, L.; Mailhe, M.; Doudier, B.; Courjon, J.; Giordanengo, V.; Vieira, V.E.; et al. Hydroxychloroquine and azithromycin as a treatment of COVID-19: Results of an open-label non-randomized clinical trial. Int. J. Antimicrob. Agents 2020, 56, 105949. [CrossRef] [PubMed]

4. Liu, J.; Cao, R.; Xu, M.; Wang, X.; Zhang, H.; Hu, H.; Li, Y.; Hu, Z.; Zhong, W.; Wang, M. Hydroxychloroquine, a less toxic derivative of chloroquine, is effective in inhibiting SARS-CoV-2 infection in vitro. Cell Discov. 2020, 6, 16. [CrossRef] [PubMed]

5. McCarty, M.F; DiNicolantonio, J.J. Nutraceuticals have potential for boosting the type 1 interferon response to RNA viruses including influenza and coronavirus. Prog. Cardiovasc. Dis. 2020, 63, 383-385. [CrossRef]

6. Zhang, R.; Wang, X.; Ni, L.; Di, X.; Ma, B.; Niu, S.; Liu, C.; Reiter, R.J. COVID-19: Melatonin as a potential adjuvant treatment. Life Sci. 2020, 250, 117583. [CrossRef]

7. Grant, W.B.; Lahore, H.; McDonnell, S.L.; Baggerly, C.A.; French, C.B.; Aliano, J.L.; Bhattoa, H.P. Evidence that Vitamin D supplementation could reduce risk of influenza and COVID-19 infections and deaths. Nutrients 2020, 12, 988. [CrossRef] 
8. Santini, A.; Cammarata, S.M.; Capone, G.; Ianaro, A.; Tenore, G.C.; Pani, L.; Novellino, E. Nutraceuticals: Opening the debate for a regulatory framework. Br. J. Clin. Pharmacol. 2018, 84, 659-672. [CrossRef]

9. Aronson, J.K. Defining 'nutraceuticals': Neither nutritious nor pharmaceutical. Br. J. Clin. Pharmacol. 2017, 83, 8-19. [CrossRef]

10. Berger, M.M.; Pichard, C. Development and current use of parenteral nutrition in critical care-An opinion paper. Crit. Care 2014, 18, 478. [CrossRef]

11. Pierre, J.F.; Heneghan, A.F.; Lawson, C.M.; Wischmeyer, P.E.; Kozar, R.A.; Kudsk, K.A. Pharmaconutrition review: Physiological mechanisms. JPEN J. Parenter. Enteral Nutr. 2013, 37 (Suppl. S5), 51S-65S. [CrossRef]

12. Heyland, D.K.; Dhaliwal, R.; Drover, J.W.; Gramlich, L.; Dodek, P. Canadian clinical practice guidelines for nutrition support in mechanically ventilated, critically ill adult patients. JPEN J. Parenter. Enteral Nutr. 2003, 27, 355-373. [CrossRef]

13. Dhaliwal, R.; Cahill, N.; Lemieux, M.; Heyland, D.K. The Canadian critical care nutrition guidelines in 2013: An update on current recommendations and implementation strategies. Nutr. Clin. Pract. 2014, 29, $29-43$. [CrossRef]

14. Singer, P.; Blaser, A.R.; Berger, M.M.; Alhazzani, W.; Calder, P.C.; Casaer, M.P.; Hiesmayr, M.; Mayer, K.; Montejo, J.C.; Pichard, C.; et al. ESPEN guideline on clinical nutrition in the intensive care unit. Clin. Nutr. 2019, 38, 48-79. [CrossRef]

15. Read, S.A.; Obeid, S.; Ahlenstiel, C.; Ahlenstiel, G. The Role of Zinc in Antiviral Immunity. Adv. Nutr. 2019, 10, 696-710. [CrossRef]

16. Kumel, G.; Schrader, S.; Zentgraf, H.; Daus, H.; Brendel, M. The mechanism of the antiherpetic activity of zinc sulphate. J. Gen. Virol. 1990, 71 Pt 12, 2989-2997. [CrossRef]

17. Gaman, A.M.; Buga, A.M.; Gaman, M.A.; Popa-Wagner, A. The role of oxidative stress and the effects of antioxidants on the incidence of infectious complications of chronic lymphocytic leukemia. Oxid. Med. Cell Longev. 2014, 2014, 158135. [CrossRef]

18. Tofolean, I.T.; Ganea, C.; Ionescu, D.; Filippi, A.; Garaiman, A.; Goicea, A.; Gaman, M.A.; Dimancea, A.; Baran, I. Cellular determinants involving mitochondrial dysfunction, oxidative stress and apoptosis correlate with the synergic cytotoxicity of epigallocatechin-3-gallate and menadione in human leukemia Jurkat T cells. Pharmacol. Res. 2016, 103, 300-317. [CrossRef]

19. Brambilla, D.; Mancuso, C.; Scuderi, M.R.; Bosco, P.; Cantarella, G.; Lempereur, L.; Di Benedetto, G.; Pezzino, S.; Bernardini, R. The role of antioxidant supplement in immune system, neoplastic, and neurodegenerative disorders: A point of view for an assessment of the risk/benefit profile. Nutr. J. 2008, 7, 29. [CrossRef]

20. Colunga Biancatelli, R.M.L.; Berrill, M.; Marik, P.E. The antiviral properties of vitamin C. Expert Rev. Anti Infect. Ther. 2020, 18, 99-101. [CrossRef]

21. Hemila, H. Vitamin C and SARS coronavirus. J. Antimicrob. Chemother. 2003, 52, 1049-1050. [CrossRef]

22. Carr, A.C.; Maggini, S. Vitamin C and Immune Function. Nutrients 2017, 9, 1211. [CrossRef]

23. Hemila, H.; Chalker, E. Vitamin C for preventing and treating the common cold. Cochrane Database Syst. Rev. 2013, 1, CD000980. [CrossRef]

24. Wang, Y.; Lin, H.; Lin, B.W.; Lin, J.D. Effects of different ascorbic acid doses on the mortality of critically ill patients: A meta-analysis. Ann. Intensive Care 2019, 9, 58. [CrossRef]

25. Padayatty, S.J.; Sun, H.; Wang, Y.; Riordan, H.D.; Hewitt, S.M.; Katz, A.; Wesley, R.A.; Levine, M. Vitamin C pharmacokinetics: Implications for oral and intravenous use. Ann. Intern. Med. 2004, 140, 533-537. [CrossRef]

26. Santos, H.O.; Teixeira, F.J.; Schoenfeld, B.J. Dietary vs. pharmacological doses of zinc: A clinical review. Clin. Nutr. 2019, 39, 1345-1353. [CrossRef]

27. Santos, H.O.; Teixeira, F.J. Use of medicinal doses of zinc as a safe and efficient coadjutant in the treatment of male hypogonadism. Aging Male 2019, 1-10. [CrossRef]

28. Wang, X.; Zheng, W.; Fang, X.; Chen, L.; Rink, L.; Min, J.; Wang, F. Zinc supplementation improves glycemic control for diabetes prevention and management: A systematic review and meta-analysis of randomized controlled trials. Am. J. Clin. Nutr. 2019, 110, 76-90. [CrossRef]

29. Wang, L.J.; Wang, M.Q.; Hu, R.; Yang, Y.; Huang, Y.S.; Xian, S.X.; Lu, L. Effect of zinc supplementation on maintenance hemodialysis patients: A systematic review and meta-analysis of 15 randomized controlled trials. Biomed. Res. Int. 2017, 2017, 1024769. [CrossRef] 
30. Ranasinghe, P.; Wathurapatha, W.S.; Ishara, M.H.; Jayawardana, R.; Galappatthy, P.; Katulanda, P.; Constantine, G.R. Effects of Zinc supplementation on serum lipids: A systematic review and meta-analysis. Nutr. Metab. 2015, 12, 26. [CrossRef]

31. Guo, J.; Xie, J.; Zhou, B.; Găman, M.-A.; Kord-Varkaneh, H.; Clark, C.C.T.; Salehi-Sahlabadi, A.; Li, Y.; Han, X.; Hao, Y.; et al. The influence of zinc supplementation on IGF-1 levels in humans: A systematic review and meta-analysis. J. King Saud Uni. 2020, 32, 1824-1830. [CrossRef]

32. Liu, K.; Chen, Y.; Lin, R.; Han, K. Clinical features of COVID-19 in elderly patients: A comparison with young and middle-aged patients. J. Infect. 2020, 80, e14-e18. [CrossRef] [PubMed]

33. Te Velthuis, A.J.; van den Worm, S.H.; Sims, A.C.; Baric, R.S.; Snijder, E.J.; van Hemert, M.J. Zn(2+) inhibits coronavirus and arterivirus RNA polymerase activity in vitro and zinc ionophores block the replication of these viruses in cell culture. PLoS Pathog. 2010, 6, e1001176. [CrossRef] [PubMed]

34. Hemila, H.; Petrus, E.J.; Fitzgerald, J.T.; Prasad, A. Zinc acetate lozenges for treating the common cold: An individual patient data meta-analysis. Br. J. Clin. Pharmacol. 2016, 82, 1393-1398. [CrossRef] [PubMed]

35. Prasad, A.S.; Beck, F.W.; Bao, B.; Snell, D.; Fitzgerald, J.T. Duration and severity of symptoms and levels of plasma interleukin-1 receptor antagonist, soluble tumor necrosis factor receptor, and adhesion molecules in patients with common cold treated with zinc acetate. J. Infect. Dis. 2008, 197, 795-802. [CrossRef]

36. Prasad, A.S.; Fitzgerald, J.T.; Bao, B.; Beck, F.W.; Chandrasekar, P.H. Duration of symptoms and plasma cytokine levels in patients with the common cold treated with zinc acetate. A randomized, double-blind, placebo-controlled trial. Ann. Intern. Med. 2000, 133, 245-252. [CrossRef]

37. Petrus, E.J.; Lawson, K.A.; Bucci, L.R.; Blum, K. Randomized, double-masked, placebo-controlled clinical study of the effectiveness of zinc acetate lozenges on common cold symptoms in allergy-tested subjects. Curr. Ther. Res. 1998, 59, 595-607. [CrossRef]

38. Hemila, H. Zinc lozenges and the common cold: A meta-analysis comparing zinc acetate and zinc gluconate, and the role of zinc dosage. JRSM Open 2017, 8, 2054270417694291. [CrossRef]

39. Mossad, S.B.; Macknin, M.L.; Medendorp, S.V.; Mason, P. Zinc gluconate lozenges for treating the common cold. A randomized, double-blind, placebo-controlled study. Ann. Intern. Med. 1996, 125, 81-88. [CrossRef]

40. Turner, R.B.; Cetnarowski, W.E. Effect of treatment with zinc gluconate or zinc acetate on experimental and natural colds. Clin. Infect. Dis. 2000, 31, 1202-1208. [CrossRef]

41. Godfrey, J.C.; Conant Sloane, B.; Smith, D.S.; Turco, J.H.; Mercer, N.; Godfrey, N.J. Zinc gluconate and the common cold: A controlled clinical study. J. Int. Med. Res. 1992, 20, 234-246. [CrossRef]

42. Eby, G.A.; Davis, D.R.; Halcomb, W.W. Reduction in duration of common colds by zinc gluconate lozenges in a double-blind study. Antimicrob. Agents Chemother. 1984, 25, 20-24. [CrossRef]

43. Matthews, L.R.; Ahmed, Y.; Wilson, K.L.; Griggs, D.D.; Danner, O.K. Worsening severity of vitamin D deficiency is associated with increased length of stay, surgical intensive care unit cost, and mortality rate in surgical intensive care unit patients. Am. J. Surg. 2012, 204, 37-43. [CrossRef] [PubMed]

44. Holick, M.F.; Binkley, N.C.; Bischoff-Ferrari, H.A.; Gordon, C.M.; Hanley, D.A.; Heaney, R.P.; Murad, M.H.; Weaver, C.M. Evaluation, treatment, and prevention of vitamin D deficiency: An Endocrine Society clinical practice guideline. J. Clin. Endocrinol. Metab. 2011, 96, 1911-1930. [CrossRef] [PubMed]

45. Brockman-Schneider, R.A.; Pickles, R.J.; Gern, J.E. Effects of vitamin D on airway epithelial cell morphology and rhinovirus replication. PLoS ONE 2014, 9, e86755. [CrossRef] [PubMed]

46. Telcian, A.G.; Zdrenghea, M.T.; Edwards, M.R.; Laza-Stanca, V.; Mallia, P.; Johnston, S.L.; Stanciu, L.A. Vitamin D increases the antiviral activity of bronchial epithelial cells in vitro. Antiviral Res. 2017, 137, 93-101. [CrossRef]

47. Wang, H.; Chen, W.; Li, D.; Yin, X.; Zhang, X.; Olsen, N.; Zheng, S.G. Vitamin D and chronic diseases. Aging Dis. 2017, 8, 346-353. [CrossRef]

48. Zhang, Y.; Jiang, X.; Li, X.; Gaman, M.A.; Kord-Varkaneh, H.; Rahmani, J.; Salehi-Sahlabadi, A.; Day, A.S.; $\mathrm{Xu}, \mathrm{Y}$. Serum vitamin $\mathrm{D}$ levels and risk of liver cancer: A systematic review and dose-response meta-analysis of cohort studies. Nutr. Cancer 2020, 1-9. [CrossRef]

49. Li, Y.; Ding, S. Serum 25-Hydroxyvitamin D and the risk of mortality in adult patients with Sepsis: A meta-analysis. BMC Infect. Dis. 2020, 20, 189. [CrossRef] 
50. Amrein, K.; Schnedl, C.; Holl, A.; Riedl, R.; Christopher, K.B.; Pachler, C.; Urbanic Purkart, T.; Waltensdorfer, A.; Munch, A.; Warnkross, H.; et al. Effect of high-dose vitamin D3 on hospital length of stay in critically ill patients with vitamin D deficiency: The VITdAL-ICU randomized clinical trial. JAMA 2014, 312, 1520-1530. [CrossRef]

51. Langlois, P.L.; Szwec, C.; D'Aragon, F.; Heyland, D.K.; Manzanares, W. Vitamin D supplementation in the critically ill: A systematic review and meta-analysis. Clin. Nutr. 2018, 37, 1238-1246. [CrossRef]

52. Hastie, C.E.; Mackay, D.F.; Ho, F.; Celis-Morales, C.A.; Katikireddi, S.V.; Niedzwiedz, C.L.; Jani, B.D.; Welsh, P.; Mair, F.S.; Gray, S.R.; et al. Vitamin D concentrations and COVID-19 infection in UK Biobank. Diabetes Metab. Syndr. 2020, 14, 561-565. [CrossRef] [PubMed]

53. Kohn, A.; Gitelman, J.; Inbar, M. Interaction of polyunsaturated fatty acids with animal cells and enveloped viruses. Antimicrob. Agents Chemother. 1980, 18, 962-968. [CrossRef] [PubMed]

54. Kohn, A.; Gitelman, J.; Inbar, M. Unsaturated free fatty acids inactivate animal enveloped viruses. Arch. Virol. 1980, 66, 301-307. [CrossRef] [PubMed]

55. Gutierrez, S.; Svahn, S.L.; Johansson, M.E. Effects of Omega-3 Fatty Acids on Immune Cells. Int. J. Mol. Sci. 2019, 20, 5028. [CrossRef]

56. Koekkoek, W.K.; Panteleon, V.; van Zanten, A.R. Current evidence on omega-3 fatty acids in enteral nutrition in the critically ill: A systematic review and meta-analysis. Nutrition 2019, 59, 56-68. [CrossRef]

57. Langlois, P.L.; D'Aragon, F.; Hardy, G.; Manzanares, W. Omega-3 polyunsaturated fatty acids in critically ill patients with acute respiratory distress syndrome: A systematic review and meta-analysis. Nutrition 2019, 61, 84-92. [CrossRef]

58. Tao, W.; Li, P.S.; Shen, Z.; Shu, Y.S.; Liu, S. Effects of omega-3 fatty acid nutrition on mortality in septic patients: A meta-analysis of randomized controlled trials. BMC Anesthesiol. 2016, 16, 39. [CrossRef]

59. Stapleton, R.D.; Martin, T.R.; Weiss, N.S.; Crowley, J.J.; Gundel, S.J.; Nathens, A.B.; Akhtar, S.R.; Ruzinski, J.T.; Caldwell, E.; Curtis, J.R.; et al. A phase II randomized placebo-controlled trial of omega-3 fatty acids for the treatment of acute lung injury. Crit. Care Med. 2011, 39, 1655-1662. [CrossRef]

60. Wu, G.; Wu, Z.; Dai, Z.; Yang, Y.; Wang, W.; Liu, C.; Wang, B.; Wang, J.; Yin, Y. Dietary requirements of "nutritionally non-essential amino acids" by animals and humans. Amino Acids 2013, 44, 1107-1113. [CrossRef]

61. Zhou, M.; Martindale, R.G. Arginine in the critical care setting. J. Nutr. 2007, 137 (Suppl. S2), 1687S-1692S. [CrossRef]

62. Yu, Y.M.; Ryan, C.M.; Castillo, L.; Lu, X.M.; Beaumier, L.; Tompkins, R.G.; Young, V.R. Arginine and ornithine kinetics in severely burned patients: Increased rate of arginine disposal. Am. J. Physiol. Endocrinol. Metab. 2001, 280, E509-E517. [CrossRef] [PubMed]

63. King, N.E.; Rothenberg, M.E.; Zimmermann, N. Arginine in asthma and lung inflammation. J. Nutr. 2004, 134 (Suppl. S10), 2830S-2836S, discussion 2853S. [CrossRef] [PubMed]

64. Forstermann, U.; Sessa, W.C. Nitric oxide synthases: Regulation and function. Eur. Heart J. 2012, 33, 829-837, 837a-837d. [CrossRef] [PubMed]

65. Xu, W.; Kaneko, F.T.; Zheng, S.; Comhair, S.A.; Janocha, A.J.; Goggans, T.; Thunnissen, F.B.; Farver, C.; Hazen, S.L.; Jennings, C.; et al. Increased arginase II and decreased NO synthesis in endothelial cells of patients with pulmonary arterial hypertension. FASEB J. 2004, 18, 1746-1748. [CrossRef] [PubMed]

66. Grasemann, H.; Schwiertz, R.; Grasemann, C.; Vester, U.; Racke, K.; Ratjen, F. Decreased systemic bioavailability of L-arginine in patients with cystic fibrosis. Respir. Res. 2006, 7, 87. [CrossRef] [PubMed]

67. Morris, C.R.; Morris, S.M., Jr.; Hagar, W.; Van Warmerdam, J.; Claster, S.; Kepka-Lenhart, D.; Machado, L.; Kuypers, F.A.; Vichinsky, E.P. Arginine therapy: A new treatment for pulmonary hypertension in sickle cell disease? Am. J. Respir. Crit. Care Med. 2003, 168, 63-69. [CrossRef]

68. Nicholas, J.; Kenyon, M.L.; Jennifer, M.; Bratt, V.; Kwan, W.; O’Roark, E.; Linderholm, A. 1-Arginine Supplementation and Metabolism in Asthma. Pharmaceuticals 2011, 4, 187-201.

69. Cascella, M.; Rajnik, M.; Cuomo, A.; Dulebohn, S.C.; Di Napoli, R. Features, evaluation and treatment Coronavirus (COVID-19). In Statpearls; StatPearls Publishing: Treasure Island, FL, USA, 2020.

70. McNeal, C.J.; Meininger, C.J.; Wilborn, C.D.; Tekwe, C.D.; Wu, G. Safety of dietary supplementation with arginine in adult humans. Amino Acids 2018, 50, 1215-1229. [CrossRef]

71. Andrews, F.J.; Griffiths, R.D. Glutamine: Essential for immune nutrition in the critically ill. Br. J. Nutr. 2002, 87 (Suppl. S1), S3-S8. [CrossRef] 
72. Griffiths, R.D. Outcome of critically ill patients after supplementation with glutamine. Nutrition 1997, 13, 752-754. [CrossRef]

73. Cruzat, V.; Macedo Rogero, M.; Noel Keane, K.; Curi, R.; Newsholme, P. Glutamine: Metabolism and immune function, supplementation and clinical translation. Nutrients 2018, 10, 1564. [CrossRef] [PubMed]

74. Jose, R.J.; Manuel, A. COVID-19 cytokine storm: The interplay between inflammation and coagulation. Lancet Respir. Med. 2020, 8, E46-E47. [CrossRef]

75. Wischmeyer, P.E.; Kahana, M.; Wolfson, R.; Ren, H.; Musch, M.M.; Chang, E.B. Glutamine reduces cytokine release, organ damage, and mortality in a rat model of endotoxemia. Shock 2001, 16, 398-402. [CrossRef] [PubMed]

76. Coeffier, M.; Marion, R.; Ducrotte, P.; Dechelotte, P. Modulating effect of glutamine on IL-1beta-induced cytokine production by human gut. Clin. Nutr. 2003, 22, 407-413. [CrossRef]

77. Stehle, P.; Ellger, B.; Kojic, D.; Feuersenger, A.; Schneid, C.; Stover, J.; Scheiner, D.; Westphal, M. Glutamine dipeptide-supplemented parenteral nutrition improves the clinical outcomes of critically ill patients: A systematic evaluation of randomised controlled trials. Clin. Nutr. ESPEN 2017, 17, 75-85. [CrossRef]

78. Dupertuis, Y.M.; Raguso, C.A.; Pichard, C. Basics in clinical nutrition: Nutrients which influence immunity-Clinical and experimental data. Clin. Nutr. ESPEN 2008, 4, e7-e9. [CrossRef]

79. Savy, G.K. Enteral glutamine supplementation: Clinical review and practical guidelines. Nutr. Clin. Pract. 1997, 12, 259-262. [CrossRef]

80. Van Zanten, A.R.; Dhaliwal, R.; Garrel, D.; Heyland, D.K. Enteral glutamine supplementation in critically ill patients: A systematic review and meta-analysis. Crit. Care 2015, 19, 294. [CrossRef]

81. Stehle, P.; Kuhn, K.S. Glutamine: An obligatory parenteral nutrition substrate in critical care therapy. Biomed. Res. Int. 2015, 2015, 545467. [CrossRef]

82. Ramezani Ahmadi, A.; Rayyani, E.; Bahreini, M.; Mansoori, A. The effect of glutamine supplementation on athletic performance, body composition, and immune function: A systematic review and a meta-analysis of clinical trials. Clin. Nutr. 2019, 38, 1076-1091. [CrossRef]

83. Zhu, L.; She, Z.G.; Cheng, X.; Qin, J.J.; Zhang, X.J.; Cai, J.; Lei, F.; Wang, H.; Xie, J.; Wang, W. Association of blood glucose control and outcomes in patients with COVID-19 and pre-existing type 2 diabetes. Cell Metab. 2020, 31, 1068-1077. [CrossRef] [PubMed]

84. Samocha-Bonet, D.; Obeid, S.; Ahlenstiel, C.; Ahlenstiel, G. Glycemic effects and safety of L-Glutamine supplementation with or without sitagliptin in type 2 diabetes patients-a randomized study. PLoS ONE 2014, 9, e113366. [CrossRef] [PubMed]

85. Ashor, A.W.; Werner, A.D.; Lara, J.; Willis, N.D.; Mathers, J.C.; Siervo, M. Effects of vitamin C supplementation on glycaemic control: A systematic review and meta-analysis of randomised controlled trials. Eur. J. Clin. Nutr. 2017, 71, 1371-1380. [CrossRef] [PubMed]

86. Jayawardena, R.; Ranasinghe, P.; Galappatthy, P.; Malkanthi, R.; Constantine, G.; Katulanda, P. Effects of zinc supplementation on diabetes mellitus: A systematic review and meta-analysis. Diabetol. Metab. Syndr. 2012, 4, 13. [CrossRef] [PubMed]

87. Dechelotte, P.; Hasselmann, M.; Cynober, L.; Allaouchiche, B.; Coeffier, M.; Hecketsweiler, B.; Merle, V.; Mazerolles, M.; Samba, D.; Guillou, Y.M.; et al. L-alanyl-L-glutamine dipeptide-supplemented total parenteral nutrition reduces infectious complications and glucose intolerance in critically ill patients: The French controlled, randomized, double-blind, multicenter study. Crit. Care Med. 2006, 34, 598-604. [CrossRef]

88. Marreiro, D.D.; Cruz, K.J.; Morais, J.B.; Beserra, J.B.; Severo, J.S.; de Oliveira, A.R. Zinc and oxidative stress: Current mechanisms. Antioxidants 2017, 6, 24. [CrossRef]

89. Matough, F.A.; Budin, S.B.; Hamid, Z.A.; Alwahaibi, N.; Mohamed, J. The role of oxidative stress and antioxidants in diabetic complications. Sultan Qaboos Univ. Med. J. 2012, 12, 5-18. [CrossRef]

90. Santos, H.O.; da Silva, G.A.R. To what extent does cinnamon administration improve the glycemic and lipid profiles? Clin. Nutr. ESPEN 2018, 27, 1-9. [CrossRef]

91. Santos, H.O.; Bueno, A.A.; Mota, J.F. The effect of artichoke on lipid profile: A review of possible mechanisms of action. Pharmacol. Res. 2018, 137, 170-178. [CrossRef]

92. Santos, H.O.; Macedo, R.C.O. Cocoa-induced (Theobroma cacao) effects on cardiovascular system: HDL modulation pathways. Clin. Nutr. ESPEN 2018, 27, 10-15. [CrossRef]

93. Higgins, J.P.; Thompson, S.G.; Deeks, J.J.; Altman, D.G. Measuring inconsistency in meta-analyses. BMJ 2003, 327, 557-560. [CrossRef] [PubMed] 
94. Feingold, K.R.; Anawalt, B.; Boyce, A.; Chrousos, G.; de Herder, W.; Dungan, K.; Grossman, A.; Hershman, J.; Hofland, H.; Kaltsas, G.; et al. Dietary reference intakes (DRIs): Tolerable upper intake levels (UL a) for vitamins (130) food and nutrition board, Institute of Medicine, National Academies. Tables 17 and 18. In Dietary Treatment of Obesity; MDText.com, Inc.: South Dartmouth, MA, USA, 2000.

95. Peter, S.; Navis, G.; de Borst, M.H.; von Schacky, C.; van Orten-Luiten, A.C.B.; Zhernakova, A.; Witkamp, R.F.; Janse, A.; Weber, P.; Bakker, S.J.L.; et al. Public health relevance of drug-nutrition interactions. Eur. J. Nutr. 2017, 56 (Suppl. S2), 23-36. [CrossRef] [PubMed]

96. Dobrica, E.C.; Gaman, M.A.; Cozma, M.A.; Bratu, O.G.; Pantea Stoian, A.; Diaconu, C.C. Polypharmacy in type 2 diabetes mellitus: Insights from an internal medicine department. Medicina 2019, 55, 436. [CrossRef] [PubMed]

(C) 2020 by the authors. Licensee MDPI, Basel, Switzerland. This article is an open access article distributed under the terms and conditions of the Creative Commons Attribution (CC BY) license (http://creativecommons.org/licenses/by/4.0/). 